\title{
Synthesis of Kojic Ester Derivatives as Potential Antibacterial Agent
}

\author{
Carolynne Zie Wei Sie $\mathbb{B}^{0}$, Zainab Ngaini $\mathbb{D}$, Nurashikin Suhaili, and Eswaran Madiahlagan
}

Faculty of Resource Science and Technology, Universiti Malaysia Sarawak, 94300 Kota Samarahan, Sarawak, Malaysia

Correspondence should be addressed to Zainab Ngaini; nzainab@unimas.my

Received 13 January 2018; Revised 9 March 2018; Accepted 19 March 2018; Published 6 May 2018

Academic Editor: Gabriel Navarrete-Vazquez

Copyright ( 2018 Carolynne Zie Wei Sie et al. This is an open access article distributed under the Creative Commons Attribution License, which permits unrestricted use, distribution, and reproduction in any medium, provided the original work is properly cited.

\begin{abstract}
The search for lead product with beneficial pharmacological properties has become a great challenge and costly. Extraction and synthetic modification of bioactive compounds from natural resources has gained great attention and is cost effective. In this study, kojic acid was produced from fungal fermentation, using sago waste as substrate, and chemically incorporated with chalcones and azobenzene to form a series of kojic ester derivatives and evaluated for antibacterial activities. Kojic ester bearing halogenated chalcone demonstrated active inhibition against Staphylococcus aureus compared to that of standard ampicillin. The inhibition increased as the electronegativity of halogens decreased, while incorporation of azobenzene derivatives on kojic acid backbone demonstrated fair antibacterial activity against Escherichia coli with minimum inhibitory concentration (MIC) of 190-330 ppm. The presence of $\mathrm{C}=\mathrm{C}$ and $\mathrm{N}=\mathrm{N}$ reactive moieties in both chalcone and azo molecules contributed to the potential biological activities of the kojic acid ester.
\end{abstract}

\section{Introduction}

Kojic acid is a natural pyrone produced from fungal fermentation from various types of carbon substrates in the presence of fungi $[1,2]$. Kojic acid and its derivatives have drawn attention and were studied intensively due to its significant biological activities in medicine and pharmacological field such as antifungal, antibiotic $[3,4]$, anti-inflammatory and analgesic [5], and antibacterial [6] properties.

Many recent studies reported on chemical modification of kojic acid for various applications such as antibacterial activity [7] and dye sensitized solar cell (DSSC) [8]. Synthesis of bioactive molecules employing kojic acid as a precursor via esterification of available hydroxyl groups has been widely reported to overcome the drawbacks of its hydrophilic properties in various applications [9-12]. Esterification of kojic acid, for instance, is able to enhance the hydrophobic properties which in turn improved its performance as tyrosinase inhibitor and antioxidant $[13,14]$.

Incorporation of kojic acid into other biological active compounds has also been reported with enhanced biological activities $[15,16]$. Chalcones are an example of biological active compound which is derived from natural sources such as fruits, vegetables, spices, tea, and soy-based foodstuff [17, $18]$ and used as an intermediate precursor of flavonoids and isoflavonoids [19]. Chalcone is also commonly prepared via Claisen Schmidt condensation. The synthesis of chalcone has drawn much attentions due to the presence of its $\alpha, \beta$ unsaturated ketone moieties which contributes to various biological activities such as antimalaria [20], anticancer [21], antiprotozoal, anti-inflammatory, antibacterial, antifilarial, anticonvulsant [22], antifungal, insect antifeedant, antimutagenic [23], and antioxidant [24, 25]. The presence of halogen substituents particularly at the para position of chalcone backbone has been reported with excellent biological activities such as antibacterial [26] and anti-inflammatory [27], while azobenzene bearing aryl/alkyl and $\mathrm{N}=\mathrm{N}$ reactive moieties have been extensively reported due to its excellent antibacterial [28, 29], antioxidant [30], anti-inflammatory [31], antifungal [32], and antitumor [33] properties. Azobenzene is also recognized for its medicinal properties such as antineoplastic [34], antidiabetic [35], and antiseptic [36].

Herein, we report on the isolation of kojic acid from sago waste and utilized it as a precursor for the synthesis 
of kojic acid ester bearing chalcone $\mathbf{3 a - c}$ and azobenzene 5a-d moieties. These compounds were screened for potential antibacterial activities against $E$. coli and $S$. aureus, and the effect of different moieties towards biological activities of kojic acid was studied.

\section{Experimental}

All the reagents were used as received without any further purification. Melting points were determined in open capillary tubes and are uncorrected. The IR spectra were recorded with $\mathrm{KBr}$ on Perkin Elmer 1605 FTIR spectrophotometer. The ${ }^{1} \mathrm{H}$ NMR were recorded in $\mathrm{CDCl}_{3}$ or DMSO- $\mathrm{d}_{6}$ on JEOL ECA 500 spectrometer at $500 \mathrm{MHz}$ using TMS as internal standard. The elemental carbon hydrogen nitrogen sulphur (CHNS) elemental analyses were performed using Thermo Scientific ${ }^{\mathrm{TM}}$ FLASH $2000 \mathrm{CHNS/O}$ Analyzer.

2.1. Fermentation of Kojic Acid (1). Sago waste was used as the substrate for kojic acid fermentation. Prior to fermentation, sago waste ( $5 \mathrm{~g}$ ) was dried, ground, and sieved. The medium was supplemented with $3 \%(\mathrm{w} / \mathrm{v})$ urea and $10 \%(\mathrm{w} / \mathrm{v})$ mineral salts solution containing $\mathrm{KH}_{2} \mathrm{PO}_{4}$, (w/v) $\mathrm{MgSO}_{4} \cdot 7 \mathrm{H}_{2} \mathrm{O}$, and yeast extract. Mixed strains of Aspergillus flavus NSH9 and A. flavus Link 44-1 were added for fermentation process. The culture was incubated at $30 \pm 2^{\circ} \mathrm{C}$ in static condition for 20 days. The slurry suspension culture $(40 \mathrm{~mL})$ was extracted with ethyl acetate $(2 \times 15 \mathrm{~mL})$. The organic layer was evaporated in vacuo to form crude brown solid and recrystallized from ethanol to afford $\mathbf{1}(0.15 \mathrm{~g}, 30 \%)$ as a yellowish needle like solid; m.p. $149-150^{\circ} \mathrm{C}$ [Reported $151-154^{\circ} \mathrm{C}$ [37]]; $\nu_{\max }$ $\left(\mathrm{KBr} / \mathrm{cm}^{-1}\right) 3173(\mathrm{OH}), 2919(\mathrm{C}=\mathrm{C}), 1661(\mathrm{C}=\mathrm{O}), 1228(\mathrm{C}-\mathrm{O})$; ${ }^{1} \mathrm{H}$ NMR (500 MHz, DMSO-d $\left.\mathrm{d}_{6}\right): \delta 9.04(1 \mathrm{H}, \mathrm{s}, \mathrm{OH}-5), 8.02$ (s, 1H, H-6), $6.34(1 \mathrm{H}, \mathrm{s}, \mathrm{H}-3), 5.67(1 \mathrm{H}, \mathrm{s}, \mathrm{OH}-7), 4.29(1 \mathrm{H}$, s, H-7); ${ }^{13} \mathrm{C}$ NMR $\left(125 \mathrm{MHz}, \mathrm{DMSO}_{-} \mathrm{d}_{6}\right): \delta 174.4$ (C-4), 168.6 (C-2), 146.2 (C-5), 139.8 (C-6), 110.4 (C-3), 60.0 (C-7).

2.2. General Method for Synthesis of 4-Carboxyl Chalcone $(2 a-c)$. Acetophenone $(1.2 \mathrm{~g}, 0.1 \mathrm{mmol})$ was added to 4-carboxybenzaldehyde derivatives $(0.15 \mathrm{~g}, 0.1 \mathrm{mmol})$ in methanol $(50 \mathrm{~mL})$. $\mathrm{KOH}(1.7 \mathrm{~g}, 0.3 \mathrm{mmol})$ in methanol was added and the mixture was stirred at room temperature for $4 \mathrm{~h}$ under nitrogen atmosphere. The precipitate formed was filtered and recrystalized from ethanol to afford title compound.

4-[(E)-3-Oxo-3-phenyl-prop-1-enyl]benzoic Acid (2a). Compound 2a $(2.32 \mathrm{~g}, 92 \%)$ as a yellowish powder. m.p. 223$224^{\circ} \mathrm{C}$; (Found: C, 76.61; H, 4.37\%. $\mathrm{C}_{16} \mathrm{H}_{12} \mathrm{O}_{3}$ Requires $\mathrm{C}$, 76.2; $\mathrm{H}, 4.8 \%) ; \nu_{\max }\left(\mathrm{KBr} / \mathrm{cm}^{-1}\right) 3059(\mathrm{C}=\mathrm{CH}), 1677(\mathrm{C}=\mathrm{O})$, 1608 (COO), 1578 (aromatic); ${ }^{1} \mathrm{H}$ NMR (500 MHz, DMSO$\left.\mathrm{d}_{6}\right): \delta 8.17(2 \mathrm{H}, \mathrm{d}, J=7.45 \mathrm{~Hz}, \mathrm{H}-3), 8.05(1 \mathrm{H}, \mathrm{d}, J=16.05 \mathrm{~Hz}$, $\mathrm{H}-\beta), 8.02(2 \mathrm{H}, \mathrm{d}, J=8.06 \mathrm{~Hz}, \mathrm{H}-8), 7.99(2 \mathrm{H}, \mathrm{d}, J=8.00 \mathrm{~Hz}$, $\mathrm{H}-2), 7.78(1 \mathrm{H}, \mathrm{d}, J=15.45 \mathrm{~Hz}, \mathrm{H}-\alpha) ; .69(1 \mathrm{H}, \mathrm{t}, J=7.73 \mathrm{~Hz}$, $\mathrm{H}-10), 7.59$ (2H, t, $J=7.75 \mathrm{~Hz}, \mathrm{H}-9)$.

4-[(E)-3-(4-Bromophenyl)-3-oxo-prop-1-enyl]benzoic Acid (2b). Compound $\mathbf{2 b}(2.65 \mathrm{~g}, 88 \%)$ as a yellowish powder; m.p. 246$247^{\circ} \mathrm{C}$; (Found: $\mathrm{C}, 58.44 ; \mathrm{H}, 3.65 \% . \mathrm{C}_{16} \mathrm{H}_{11} \mathrm{BrO}_{3}$ Requires $\mathrm{C}$,
58.0; H, 3.3\%); $\nu_{\max }\left(\mathrm{KBr} / \mathrm{cm}^{-1}\right) 3064(\mathrm{C}=\mathrm{CH}), 1663(\mathrm{C}=\mathrm{O})$, 1607 (COO), 1583 (aromatic); ${ }^{1} \mathrm{H}$ NMR (500 MHz, DMSO$\left.\mathrm{d}_{6}\right): \delta 8.13(2 \mathrm{H}, \mathrm{d}, J=8.00 \mathrm{~Hz}, \mathrm{H}-8), 8.05(1 \mathrm{H}, \mathrm{d}, J=15.45 \mathrm{~Hz}$, $\mathrm{H}-\beta), 8.02(2 \mathrm{H}, \mathrm{d}, J=8.00 \mathrm{~Hz}, \mathrm{H}-3), 7.98(2 \mathrm{H}, \mathrm{d}, J=8.60 \mathrm{~Hz}$, $\mathrm{H}-9), 7.79(1 \mathrm{H}, \mathrm{d}, J=15.45 \mathrm{~Hz}, \mathrm{H}-\alpha), 7.79(2 \mathrm{H}, \mathrm{d}, J=8.00 \mathrm{~Hz}$, $\mathrm{H}-2)$.

4-[(E)-3-(4-Chlorophenyl)-3-oxo-prop-1-enyl]benzoic Acid (2c). Compound $2 \mathrm{c}(2.12 \mathrm{~g}, 74 \%)$ as a yellowish powder. m.p. 259$260^{\circ} \mathrm{C}$; (Found: C, 67.09; H, 3.27\%. $\mathrm{C}_{16} \mathrm{H}_{11} \mathrm{ClO}_{3}$ Requires C, 67.0; H, 3.9\%); $\nu_{\max }\left(\mathrm{KBr} / \mathrm{cm}^{-1}\right) 2943(\mathrm{C}=\mathrm{CH}), 1678(\mathrm{C}=\mathrm{O})$, 1612 (COO), 1577 (aromatic); ${ }^{1} \mathrm{H}$ NMR (500 MHz, DMSO$\left.\mathrm{d}_{6}\right): \delta 8.20(2 \mathrm{H}, \mathrm{d}, J=8.40 \mathrm{~Hz}, \mathrm{H}-8), 8.00(1 \mathrm{H}, \mathrm{d}, J=16.05 \mathrm{~Hz}$, $\mathrm{H}-\beta), 7.93(2 \mathrm{H}, \mathrm{d}, J=8.40 \mathrm{~Hz}, \mathrm{H}-3), 7.90(2 \mathrm{H}, \mathrm{d}, J=8.40 \mathrm{~Hz}$, $\mathrm{H}-9), 7.78(1 \mathrm{H}, \mathrm{d}, J=16.05 \mathrm{~Hz}, \mathrm{H}-\alpha), 7.65(2 \mathrm{H}, \mathrm{d}, J=7.65 \mathrm{~Hz}$, H-2).

2.3. General Method for Synthesis of Kojic Acid-Chalcone Derivatives $(\mathbf{3 a}-\boldsymbol{c})$. Chalcone $\mathbf{2 a}-\mathbf{c}(1.26 \mathrm{~g}, 0.05 \mathrm{mmol})$ was added to a solution of 1 ( $0.71 \mathrm{~g}, 0.05 \mathrm{mmol})$, DMAP $(0.12 \mathrm{~g}$, $1 \mathrm{mmol})$, and DCC (1.03 g, $0.05 \mathrm{mmol})$ in DCM $(30 \mathrm{~mL})$. The reaction mixture was stirred at $0^{\circ} \mathrm{C}$ for $4 \mathrm{~h}$, washed with acetic acid $(1 \mathrm{M}, 2 \times 20 \mathrm{~mL})$, followed by $\mathrm{Na}_{2} \mathrm{CO}_{3}$ solution $(1 \mathrm{M}$, $2 \times 20 \mathrm{~mL}$ ), and dried over magnesium sulphate. The crude product obtained was purified by column chromatography over silica gel (eluting with 1:2 EA/Hex) to afford title compound.

[6-(Hydroxymethyl)-4-oxo-pyran-3-yl] 4-[(E)-3-oxo-3-phenylprop-1-enyl] Benzoate (3a). Compound 3a $(0.4 \mathrm{~g}, 23 \%)$ as a white powder. m.p. $162-163^{\circ} \mathrm{C}$; (Found: C, 69.56; H, $4.25 \%$. $\mathrm{C}_{22} \mathrm{H}_{16} \mathrm{O}_{6}$ Requires C, 70.2; H, 4.3\%); $v_{\max }\left(\mathrm{KBr} / \mathrm{cm}^{-1}\right) 2987$ $(\mathrm{C}=\mathrm{CH}), 1730(\mathrm{C}=\mathrm{O}$ ester $), 1665(\mathrm{C}=\mathrm{O}), 1644(\mathrm{C}=\mathrm{O}), 1605$ (aromatic), $1201(\mathrm{C}-\mathrm{O}) ;{ }^{1} \mathrm{H}$ NMR $\left(500 \mathrm{MHz}, \mathrm{DMSO}-\mathrm{d}_{6}\right): \delta$ 8.69 (1H, s, H-6), 8.11 (7H, m, H-9, H-10, H-15, H- $\beta), 7.79(2 \mathrm{H}$, d, $J=16.05 \mathrm{~Hz}, \mathrm{H}-\alpha), 7.67$ (1H, m, H-17), 7.59 (2H, m, H-16), 6.65 (1H, s, H-3), 5.02 (2H, s, H-7).

[6-(Hydroxymethyl)-4-oxo-pyran-3-yl]4-[(E)-3-(4-bromophenyl)-3-oxo-prop-1-enyl] Benzoate (3b). Compound 3b (0.4 g, $19 \%$ ) as a white powder. m.p. $194-195^{\circ} \mathrm{C}$; (Found: C, 58.37; $\mathrm{H}, 3.24 \%$. $\mathrm{C}_{22} \mathrm{H}_{15} \mathrm{BrO}_{6}$ Requires C, 58.0; $\left.\mathrm{H}, 3.3 \%\right)$; $\nu_{\max }\left(\mathrm{KBr} / \mathrm{cm}^{-1}\right) 2926(\mathrm{C}=\mathrm{CH}), 1697(\mathrm{C}=\mathrm{O}$ ester $), 1651$ $(\mathrm{C}=\mathrm{O}), 1623(\mathrm{C}=\mathrm{O}), 1570$ (aromatic), $1242(\mathrm{C}-\mathrm{O}) ;{ }^{1} \mathrm{H}$ NMR $\left(500 \mathrm{MHz}, \mathrm{DMSO}-\mathrm{d}_{6}\right): \delta 8.67(1 \mathrm{H}, \mathrm{s}, \mathrm{H}-6), 8.13(2 \mathrm{H}, \mathrm{d}, J=$ $8.6 \mathrm{~Hz}, \mathrm{H}-15), 8.12(2 \mathrm{H}, \mathrm{d}, J 8.00 \mathrm{~Hz}, \mathrm{H}-10), 8.04(1 \mathrm{H}, \mathrm{d}, J=$ $15.45 \mathrm{~Hz}, \mathrm{H}-\beta), 7.99(2 \mathrm{H}, \mathrm{d}, J=8.00 \mathrm{~Hz}, \mathrm{H}-16), 8.00(1 \mathrm{H}, \mathrm{d}, J$ $=12.6 \mathrm{~Hz}, \mathrm{H}-\alpha), 7.80(2 \mathrm{H}, \mathrm{d}, J=8.55 \mathrm{~Hz}, \mathrm{H}-9), 6.50(1 \mathrm{H}, \mathrm{s}$, H-3), 4.40 (2H, s, H-7).

[6-(Hydroxymethyl)-4-oxo-pyran-3-yl]4-[(E)-3-(4-chlorophenyl)-3-oxo-prop-1-enyl]benzoate (3c). Compound 3c (0.5 g, $25 \%$ ) as a white powder. m.p. 202-203 ${ }^{\circ} \mathrm{C}$; (Found: C, 63.54; $\mathrm{H}, 3.31 \% . \mathrm{C}_{22} \mathrm{H}_{15} \mathrm{ClO}_{6}$ Requires $\left.\mathrm{C}, 64.3 ; \mathrm{H}, 3.7 \%\right) ; v_{\max }$ $\left(\mathrm{KBr} / \mathrm{cm}^{-1}\right) 2927(\mathrm{C}=\mathrm{CH}), 1731(\mathrm{C}=\mathrm{O}$ ester $), 1666(\mathrm{C}=\mathrm{O})$, $1643(\mathrm{C}=\mathrm{O}), 1607$ (aromatic), 1239 (C-O); ${ }^{1} \mathrm{H}$ NMR $\left(500 \mathrm{MHz}, \mathrm{DMSO}-\mathrm{d}_{6}\right): \delta 8.67(1 \mathrm{H}, \mathrm{s}, \mathrm{H}-6), 8.13(4 \mathrm{H}, \mathrm{t}, J=$ $7.73 \mathrm{~Hz}, \mathrm{H}-15, \mathrm{H}-10), 8.04$ (1H, d, $J=14.9 \mathrm{~Hz}, \mathrm{H}-\beta), 7.99(2 \mathrm{H}$, 
d, $J=8.0 \mathrm{~Hz}, \mathrm{H}-16), 7.86(1 \mathrm{H}, \mathrm{d}, J=11.45 \mathrm{~Hz}, \mathrm{H}-\alpha), 7.79(2 \mathrm{H}$, d, $J=7.45 \mathrm{~Hz}, \mathrm{H}-9), 6.50(1 \mathrm{H}, \mathrm{s}, \mathrm{H}-3), 4.39(2 \mathrm{H}, \mathrm{s}, \mathrm{H}-7)$.

2.4. Synthesis of Azobenzene Derivatives $(\mathbf{4 a}-\boldsymbol{d}) . \mathrm{HCl}(8 \mathrm{M}$, $100 \mathrm{~mL}$ ) was added drop wise to a solution of 4-aminoethylbenzoate $(5 \mathrm{~g}, 30.0 \mathrm{mmol})$ in methanol $(50 \mathrm{~mL})$ in an ice bath at $0-5^{\circ} \mathrm{C}$. Sodium nitrite $(3.1 \mathrm{~g}, 45.0 \mathrm{mmol})$ in distilled water $(10 \mathrm{~mL})$ and phenol $(3.4 \mathrm{~g}, 36 \mathrm{mmol})$ in methanol $(50 \mathrm{~mL})$ were added drop wise to the reaction mixture. $\mathrm{NaOH}$ solution $(1 \mathrm{M}, 100 \mathrm{~mL})$ was then added drop wise to $\mathrm{pH}$ 8.5-9.5. The reaction mixture was stirred for $4 \mathrm{hr}$ under nitrogen atmosphere. Methanol $(50 \mathrm{~mL})$ was added and acidified with $\mathrm{HCl}(8 \mathrm{M}, 50 \mathrm{~mL})$ to form precipitate. The solid was filtered, washed, and recrystallized from ethanol. $\mathrm{KOH}$ $(0.13 \mathrm{~g}, 2.4 \mathrm{mmol})$ was added to the solid $(0.2 \mathrm{~g}, 0.8 \mathrm{mmol})$ in methanol $(50 \mathrm{~mL})$ and heated under reflux for $4 \mathrm{~h}$ under nitrogen atmosphere. Cold water $(30 \mathrm{~mL})$ was added to the reaction mixture, acidified with acetic acid (8M), and filtered and recrystallized from ethanol to give azobenzene intermediate. Azobenzene $(1.5 \mathrm{~g}, 5 \mathrm{mmol})$ was added to a solution of bromoalkene derivatives, $\mathrm{t}-\mathrm{BuOK}(0.62 \mathrm{~g}, 5.0 \mathrm{mmol})$ and KI $(20 \mathrm{mg})$ in acetone $(100 \mathrm{~mL})$, and heated at reflux for $48 \mathrm{~h}$ under nitrogen atmosphere. DCM $(50 \mathrm{~mL})$ and water $(30 \mathrm{~mL})$ were added and the layers were separated. The aqueous layer was extracted with DCM $(2 \times 30 \mathrm{~mL})$ and the combined organic layers were dried and evaporated under reduced pressure and recrystallized from ethanol to give title compound $\mathbf{4 a - d}$ as colorless crystals. FTIR and NMR data were consistent with the reported literature [8].

2.5. Synthesis of Kojic Acid-Azobenzene (5a-d). Thionyl chloride $(0.036 \mathrm{~g}, 0.3 \mathrm{mmol})$ was added to a solution of $\mathbf{1}(0.014 \mathrm{~g}$, $0.1 \mathrm{mmol})$ in DMF $(20 \mathrm{~mL})$ and heated under reflux for $4 \mathrm{~h}$. The reaction mixture was extracted with DCM $(2 \times 15 \mathrm{~mL})$. The organic layer was dried, filtered, and concentrated under reduced pressure to give kojyl chloride as yellowish needle solid $(0.012 \mathrm{~g}, 70 \%)$. Azo intermediate was added to a solution of kojyl chloride prepared $(0.1 \mathrm{~g}, 0.6 \mathrm{mmol})$ in DMF $(30 \mathrm{~mL})$ with TEA $(0.015 \mathrm{~g}, 0.15 \mathrm{mmol})$ in dried acetone $(20 \mathrm{~mL})$ and heated under refluxed for $24 \mathrm{~h}$. The reaction mixture was washed with dilute $\mathrm{HCl}(1 \mathrm{M}, 2 \times 20 \mathrm{~mL})$. The organic layer was dried, filtered, and concentrated under reduced pressure. Crude product was recrystallized from ethanol to afford $5 \mathbf{b}-\mathbf{e}$ as colorless crystals. FTIR and NMR data were consistent with the reported literature [8].

\subsection{Antibacterial Screening}

2.6.1. Turbidimetric Kinetic Method. The antibacterial activities of synthesized $\mathbf{4 a}-\mathbf{d}$ and $\mathbf{5 a}-\mathbf{d}$ were screened against Escherichia coli using turbidimetric kinetic method. Escherichia coli were cultured on LB plate agar for $24 \mathrm{~h}$ at $37^{\circ} \mathrm{C}$ and a single colony was transferred to the media containing nutrient broth prepared. The inoculum was allowed to grow at $37^{\circ} \mathrm{C}$ with $250 \mathrm{rpm}$ stirring overnight. Inoculum $(0.2 \mathrm{~mL})$ was added to $10 \mathrm{~mL}$ of culture medium which had been added with different concentrations (50 ppm, $80 \mathrm{ppm}$, and $100 \mathrm{ppm}$ ) of respective compounds in DMSO. Three replicates of each concentration were prepared. The control used was the medium broth of inoculums added with DMSO with no active compound. The mixture was shaken at $230 \mathrm{rpm}$ at $37^{\circ} \mathrm{C}$. The transmittances $(\mathrm{T})$ of the aliquots were taken every $1 \mathrm{~h}$ interval for six continuous hours using UV-Visible Spectrophotometer Optima SP-300. The antibacterial activity was determined from the graph of In Nt versus time plotted. The In Nt values represent the number of colony forming units (units $/ \mathrm{mL}$ ) which follows the equation of $\mathrm{In} \mathrm{Nt}=27.1$ $-8.56 \mathrm{~T}[38,39]$

2.6.2. Via Kirby Bauer Disc Diffusion Method. The antibacterial activities of the synthesized $\mathbf{2} \mathbf{a}-\mathbf{c}$ and $\mathbf{3 a}-\mathbf{c}$ were evaluated against Escherichia coli and Staphylococcus aureus using Kirby Bauer Disc Diffusion method. E. coli and S. aureus were used as inoculums and cultured in Mueller-Hinton Broth (MHB) and incubated at $37.5^{\circ} \mathrm{C}$ with constant shaking at $150 \mathrm{rpm}$ for $18 \mathrm{~h}$. The bacteria suspension prepared was inoculated onto the entire surface of a Mueller-Hinton Agar (MHA) plate with sterilised cotton tipped swab to form an even lawn. Sterilised filter paper disc impregnated with $10 \mu \mathrm{L}$ of the compound in DMSO was placed on the bacteria surface of MHA plate using a sterilised forcep. The plates were incubated at $37.5^{\circ} \mathrm{C}$ for $24 \mathrm{~h}$. The zone of inhibition was measured in millimetres $(\mathrm{mm})$ to estimate the potency of the tested compound.

\section{Results and Discussion}

3.1. Preparation of Kojic Acid via Fermentation. Kojic acid 1 was prepared via fermentation of sago hampas employing mixed strains of Aspergillus flavus NSH9 and Aspergillus flavus Link 44-1. Aspergillus flavus was used for a higher yield of $\mathbf{1}[15]$. The optimum parameters were from a combination of $3 \%(\mathrm{w} / \mathrm{v})$ urea and $10 \%$ mineral salts solution containing $\mathrm{KH}_{2} \mathrm{PO}_{4}$, (w/v) $\mathrm{MgSO}_{4} \cdot 7 \mathrm{H}_{2} \mathrm{O}$ and yeast. $\mathrm{KH}_{2} \mathrm{PO}_{4}$ and $\mathrm{MgSO}_{4}$ supported the growth of bacteria strain and boosted the production of kojic acid [40]. Yeast is a nitrogen source for metabolic activation to enhance kojic acid production. Its high levels of essential components such as vitamins and oligoelements support growth of bacteria and fermentation process [3].

3.2. Synthesis of Kojic Acid Ester Derivatives. Kojic ester 2a-c was prepared via Claisen Schmidt condensation followed by Steglich esterification with isolated kojic acid to yield $\mathbf{3 a} \mathbf{a}-\mathbf{c}$, whereas kojic ester (5a-d) was prepared via kojyl chloride [11] followed by addition of $\mathbf{4 a - d}$ to afford $5 \mathbf{a}-\mathbf{d}$ (70-87\%). The overall synthesis is shown in Scheme 1. Structures of the compounds synthesized were confirmed by elemental analysis, IR spectra, and ${ }^{1} \mathrm{H}$ NMR spectra.

The IR spectra for $2 \mathbf{a}-\mathbf{c}$ showed absorptions band at $3064-2943 \mathrm{~cm}^{-1}$ and $1678-1663 \mathrm{~cm}^{-1}$ attributed to $\mathrm{C}=\mathrm{C}$ and $\mathrm{C}=\mathrm{O}$ group of chalcone linkage. A sharp band at $1612-1607 \mathrm{~cm}^{-1}$ indicated the presence of carboxyl group. Absorption peaks at $1583-1577 \mathrm{~cm}^{-1}$ revealed the presence of aromatic group. The ${ }^{1} \mathrm{H}$ NMR showed aromatic protons of $2 \mathrm{a}$ at $\delta 8.17-7.59 \mathrm{ppm}$ as doublet and triplet while aromatic protons of $\mathbf{2 b}-\mathbf{c}$ appeared at $\delta 8.20-7.65 \mathrm{ppm}$ as four doublets with coupling constant $8-8.6 \mathrm{~Hz}$. The peaks of $\mathrm{CH}_{\alpha}$ $=\mathrm{CH}_{\beta}$ were observed at $\delta 7.79-7.78$ and $8.05-8.00 \mathrm{ppm}$ as 


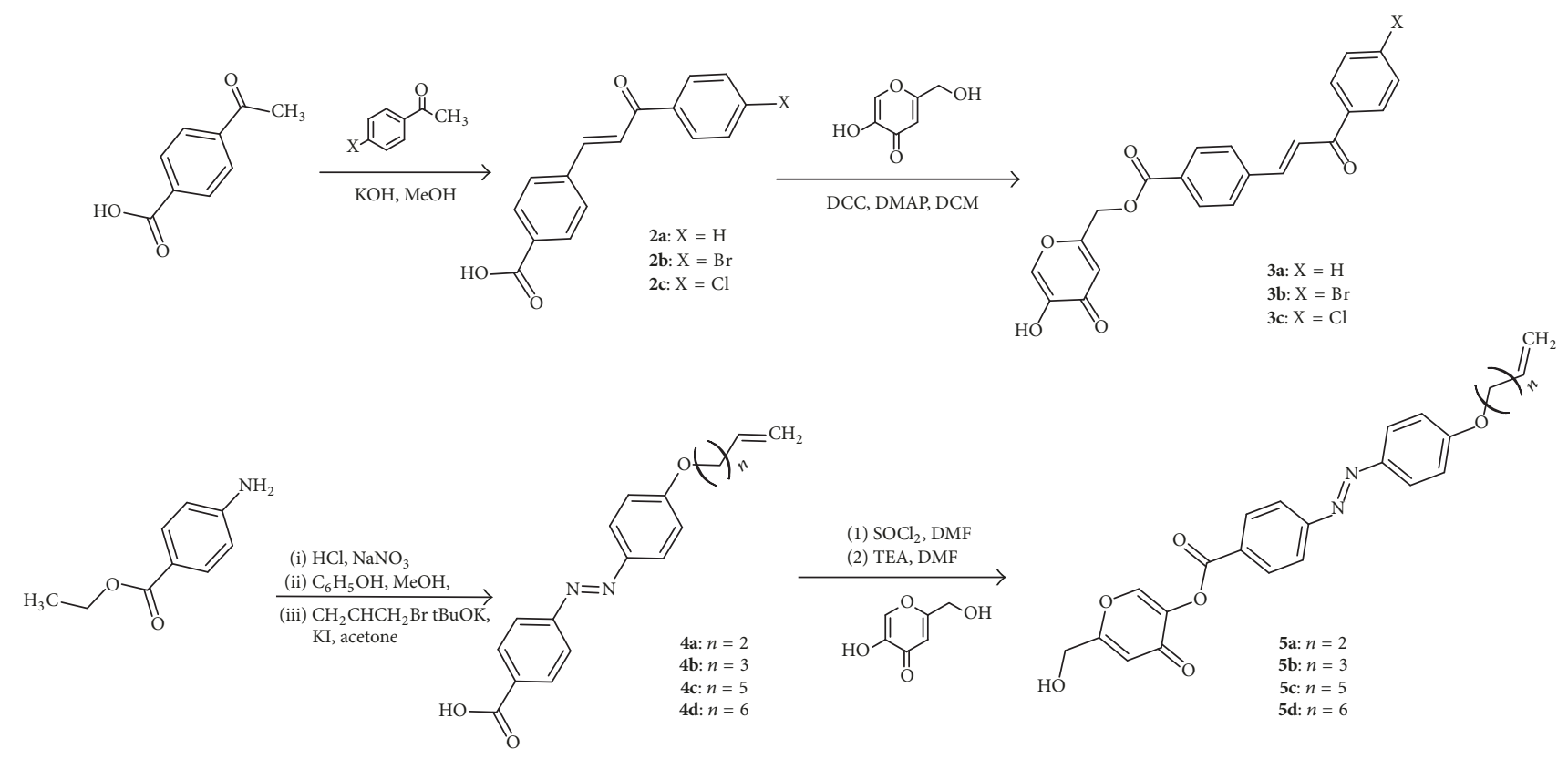

Scheme 1: Synthesis of kojic esters (3a-c) and (5a-d).

two doublets with $J_{\mathrm{ab}} 15.5-16.1 \mathrm{~Hz}$, which indicated trans configuration.

Formation of $\mathbf{3 a - c}$ was confirmed by FTIR and ${ }^{1} \mathrm{H}$ NMR spectroscopies. The IR spectrum for $3 \mathbf{a}-\mathbf{c}$ showed appearance of $\mathrm{C}=\mathrm{O}$ ester absorption band at $1731-1697 \mathrm{~cm}^{-1}$. The IR spectrum revealed two strong bands at $1666-1651 \mathrm{~cm}^{-1}$ and $1644-1623 \mathrm{~cm}^{-1}$ attributed to $v(\mathrm{C}=\mathrm{O})$ of chalcone and kojic acid, respectively. The absorption frequency at $1605-1570 \mathrm{~cm}^{-1}$ was attributed to aromatic group while $v(\mathrm{C}$ O) was represented by absorption band at $1242-1201 \mathrm{~cm}^{-1}$. The ${ }^{1} \mathrm{H}$ NMR showed that all corresponding peaks indicated the formation of $\mathbf{3 a}-\mathbf{c}$. The existence of kojic acid moieties in $3 \mathbf{a}-\mathbf{c}$ was proven by appearance of two kojic acid olefinic proton at $\delta 8.69-8.67$ and $6.65-6.50 \mathrm{ppm}$ as singlet. The oxymethyl protons of kojic acid were represented by peaks at $\delta 5.02-4.39 \mathrm{ppm}$.

The NMR spectra of kojic ester (5a-d) via formation of kojyl chloride revealed the presence of peak attributed to oxymethyl proton $\left(\mathrm{OCH}_{2}\right)$ at $\delta 5.26-5.24 \mathrm{ppm}$ as singlet, which indicated 7-O-substituent 1 [41]. In comparison to 5$O$-substituted $\mathbf{3 a}-\mathbf{c}, 7-O$-substituted $\mathbf{5 a}-\mathbf{d}$ showed shifted $\mathrm{H}$ 6 olefinic proton signals to upfield and oxymethyl proton signals to downfield. Carbonyl group of ketone is more deshielded than carbonyl group of ester due to deshielding effect of pyrone ring [42].

3.3. Antibacterial Activities of Kojic Ester Derivatives. The kojic ester derivatives $\mathbf{3 a - c}$ and $\mathbf{5 a - d}$ were evaluated for antibacterial activities against gram negative strain $E$. coli at $37^{\circ} \mathrm{C}$ via turbidimetric method at three different concentrations, $50 \mathrm{ppm}, 80 \mathrm{ppm}$, and $100 \mathrm{ppm}$, and compared to chalcones $(\mathbf{2} \mathbf{a}-\mathbf{c})$ and azobenzene $(\mathbf{4 a}-\mathbf{d})$ derivatives. Due to solubility limitation of $\mathbf{2} \mathbf{a}-\mathbf{c}$ and $\mathbf{3 a}-\mathbf{d}$ in organic solvent, turbidimetric method was only applied on $\mathbf{4 a - d}$ and
TABLe 1: MIC for $\mathbf{4 a - d}$ and $\mathbf{5 a}-\mathbf{d}$.

\begin{tabular}{lc}
\hline Compounds & MIC (ppm) \\
\hline 4a & $>400$ \\
4b & $>400$ \\
4c & $>400$ \\
4d & $>400$ \\
5a & 200 \\
5b & 190 \\
5c & 330 \\
5d & 330 \\
\hline
\end{tabular}

5a-d. Negative control, which is comprised of solvent and inoculums, showed significant increase in growth of E. coli. The antibacterial assay was expressed by plotting graph of In $N_{t}$ versus time. The In $N_{t}$ value indicated number of colony forming (growth of $E$. coli) units $/ \mathrm{mL}$ which followed the expression of In $N_{t}=27.1-8.56 \mathrm{~T}$ [39].

Kojic ester $\mathbf{4 a - d}$ exhibited weak inhibition while $\mathbf{5 a - d}$ exhibited good inhibition against $E$. coli. The inhibition of 5a-d is concentration dependent where $100 \mathrm{ppm}>80 \mathrm{ppm}$ $>50 \mathrm{ppm}$. The minimum inhibitory concentration (MIC) of $4 \mathbf{a}-\mathbf{d}$ and $5 \mathbf{a}-\mathbf{d}$ was determined by extrapolating the concentration to zero growth rate of $E$. coli. The MIC of $\mathbf{4 a - d}$ and $\mathbf{5 a}-\mathbf{d}$ is summarized in Table 1 . Kojic ester moieties in azobenzene are envisaged to increase the lipophilic properties in $\mathbf{5 a}-\mathbf{d}$ to interact and destruct the bacterial cell membrane [43]. The presence of $\mathrm{C}=\mathrm{O}$ and $\mathrm{N}=\mathrm{N}$ moieties in kojic ester offers more reactive sites that easily protonated under acidic condition and reacted with the bacterial surfaces which further enhance the biological activity [44]. Compound 5ab showed better activity than $\mathbf{5 c}$-d due to the increase of 
TABLE 2: Inhibition zones of $\mathbf{2 a - c}$ and $\mathbf{3 a - c}$.

\begin{tabular}{lcc}
\hline \multirow{2}{*}{ Compounds } & \multicolumn{2}{c}{ Zone of inhibition $(\mathrm{mm})$} \\
& E. coli & S. aureus \\
\hline 2a & - & 16.0 \\
2b & - & 13.0 \\
2c & - & 8.0 \\
3a & - & 8.0 \\
3b & - & 11.0 \\
3c & - & 13.0 \\
DMSO & - & - \\
Kojic acid & - & - \\
Ampicillin & 16.0 & 11.0 \\
\hline
\end{tabular}

chain length after the cutoff effect associated with decrease in solubility.

Antibacterial activity of kojic esters $\mathbf{2 a}-\mathbf{c}$ and $\mathbf{3 a} \mathbf{a}-\mathbf{c}$ bearing chalcone moieties was conducted by measuring the zone of inhibition on agar plates (Kirby Bauer Disc Diffusion method) against $S$. aureus and E. coli bacterial strain due to solubility limitation in DMSO. Ampicillin was used as reference standard and DMSO as negative control.

The zone inhibition of $\mathbf{2 a - c}$ and $\mathbf{3} \mathbf{a}-\mathbf{c}$ is shown in Table 2. Kojic acid showed no inhibition against both $S$. aureus and $E$. coli, while both series of $\mathbf{2 a}-\mathbf{c}$ and $\mathbf{3 a}-\mathbf{c}$ showed no inhibition against $E$. coli compared to standard ampicillin. Compounds 2a-c and 3a-c, however, showed active inhibition against $S$. aureus with $\mathbf{2 c}$ and $\mathbf{3} \mathbf{a}-\mathbf{b}$ being inhibited better than ampicillin. The selective antibacterial activity of $\mathbf{2 a}-\mathbf{c}$ and $\mathbf{3 a}-\mathbf{c}$ against gram positive bacterial strain is due to the significance different in the membrane composition and architecture of gram positive and gram negative organism [45]. S. aureus has simpler mesh like cell membrane compared to $E$. coli which eases the penetration of compound [46].

Antibacterial activities of $2 \mathbf{a}-\mathbf{c}$ increased with the decrease in electronegativity of substituent on chalcone. Electronegativity in decreasing order is as follows: $\mathrm{Cl}(8 \mathrm{~mm})$ $>\mathrm{Br}(13 \mathrm{~mm})>\mathrm{H}(16 \mathrm{~mm})$. Polarized ability of antibacterial agent increases with the decreased in electronegativity which reasoned to enhance activity of acting antibacterial agent [47].

The antibacterial activities of $\mathbf{3 a}-\mathbf{c}$, however, showed an opposite trend. The inhibition was increased with the increased in electronegativity. The incorporation of kojic acid transformed the lipophilic properties of the compound. A good balance between hydrophilic and hydrophobic properties of compound makes good antibacterial agent [48]. Compound $3 \mathrm{c}$ with chlorine substituents showed the biggest zone of inhibition with $13 \mathrm{~mm}$ while $3 \mathbf{a}$ with hydrogen showed the least zone of inhibition $(8 \mathrm{~mm})$.

\section{Conclusions}

A series of kojic esters $\mathbf{2 a}-\mathbf{c}$ and $\mathbf{3} \mathbf{a}-\mathbf{c}$ has been successfully synthesized and exhibited good antibacterial activity towards gram positive $S$. aureus bacteria strain. Antibacterial activities of $\mathbf{2 a - c}$ increased with the decrease in electronegativity of halogen substituent on chalcone with $2 \mathrm{c}$ showing the highest inhibition, better than the ampicillin reference standard. Lipophilic properties of kojic ester bearing chalcone derivatives 3a-b inhibited better antibacterial activity. Kojic ester $5 \mathbf{a}-\mathbf{d}$ bearing azobenzene derivatives showed good inhibition against E. Coli compared to $\mathbf{4 a - d}$. The presence of $\mathrm{C}=\mathrm{O}$ ester, $\mathrm{N}=\mathrm{N}$, and alkene chains has increased the lipophilic properties of of $5 \mathbf{a}-\mathbf{d}$ and disrupts the bacteria cell walls.

\section{Conflicts of Interest}

The authors declare that there are no conflicts of interest regarding the publication of this paper.

\section{Acknowledgments}

This work was supported by Universiti Malaysia Sarawak and Ministry of Education for Research Funds F07(DPP17)/1173/ 2014(17) and FRGS/ST01(02)/968/2013(09). The authors would also like to express special thanks to Professor Dr. Arbakariya Ariff from UPM for providing the A. flavus Link 441 strain.

\section{References}

[1] J. Chaudhary, A. N. Pathak, and S. Lakhawat, "Production technology and applications of kojic acid," Annual Research \& Review in Biology, vol. 4, no. 21, pp. 3165-3196, 2014.

[2] A. F. B. Lajis, M. Basri, R. Mohamad et al., "Enzymatic synthesis of kojic acid esters and their potential industrial applications," Chemical Papers, vol. 67, no. 6, pp. 573-585, 2013.

[3] S. A. El-Aasar, "Cultural conditions studies on kojic acid production by Aspergillus parasiticus," nternational Journal of Agriculture \& Biology, vol. 8, no. 4, pp. 468-473, 2006.

[4] M. D. Aytemir, D. D. Erol, R. C. Hider, and M. Özalp, "Synthesis and evaluation of antimicrobial activity of new 3-Hydroxy-6methyl-4-oxo-4H-pyran-2-carboxamide derivatives," Turkish Journal of Chemistry, vol. 26, no. 7, pp. 757-764, 2003.

[5] H. Kayahara, N. Shibata, K. Tadasa, H. Maeda, T. Kotani, and I. Ichimoto, "Amino acid and peptide derivatives of kojic acid and their antifungal properties," Agricultural and Biological Chemistry, vol. 54, no. 9, pp. 2441-2442, 1990.

[6] B. V. S. Reddy, M. R. Reddy, C. Madan, K. P. Kumar, and M. S. Rao, "Indium(III) chloride catalyzed three-component coupling reaction: a novel synthesis of 2-substituted aryl(indolyl)kojic acid derivatives as potent antifungal and antibacterial agents," Bioorganic \& Medicinal Chemistry Letters, vol. 20, no. 24, pp. 7507-7511, 2010.

[7] S. Emami, E. Ghafouri, M. A. Faramarzi, N. Samadi, H. Irannejad, and A. Foroumadi, "Mannich bases of 7-piperazinylquinolones and kojic acid derivatives: synthesis, in vitro antibacterial activity and in silico study," European Journal of Medicinal Chemistry, vol. 68, pp. 185-191, 2013.

[8] C. Z. Sie and Z. Ngaini, "Incorporation of kojic acid-azo dyes on $\mathrm{TiO}_{2}$ thin films for dye sensitized solar cells applications," Journal of Solar Energy, vol. 2017, Article ID 2760301, pp. 1-10, 2017. 
[9] K.-J. Liu and J.-F. Shaw, "Lipase-catalyzed synthesis of kojic acid esters in organic solvents," Journal of the American Oil Chemists' Society, vol. 75, no. 11, pp. 1507-1511, 1998.

[10] N. El-Boulifi, S. E. Ashari, M. Serrano, J. Aracil, and M. Martínez, "Solvent-free lipase-catalyzed synthesis of a novel hydroxyl-fatty acid derivative of kojic acid," Enzyme and Microbial Technology, vol. 55, pp. 128-132, 2014.

[11] S. R. Ho, S. B. Heung, M. A. Soo, H. K. Duck, and S. C. Ih, "Synthesis of new anti-melanogenic compounds containing two molecules of kojic acid," Bulletin of the Korean Chemical Society, vol. 29, no. 8, pp. 1569-1571, 2008.

[12] T. Kobayashi, S. Adachi, K. Nakanishi, and R. Matsuno, "Semicontinuous production of lauroyl kojic acid through lipasecatalyzed condensation in acetonitrile," Biochemical Engineering Journal, vol. 9, no. 2, pp. 85-89, 2001.

[13] H. S. Rho, M. Goh, J. Lee et al., "Ester derivatives of kojic acid and polyphenols containing adamantane moiety with tyrosinase inhibitory and anti-inflammatory properties," Bulletin of the Korean Chemical Society, vol. 32, no. 4, pp. 1411-1414, 2011.

[14] C. M. Yang, J. Y. Hong, K. W. Lee, B. G. Lee, and D. I. Chang, "Kojic Acid Derivative," United States Patent, Patent number: 5486624, 1996.

[15] C. Balakrishna, N. Payili, S. Yennam, P. Uma Devi, and M. Behera, "Synthesis of new kojic acid based unnatural $\alpha$-amino acid derivatives," Bioorganic \& Medicinal Chemistry Letters, vol. 25, no. 21, pp. 4753-4756, 2015.

[16] K. Morisaki and S. Ozaki, "Design of novel hybrid vitamin C derivatives: Thermal stability and biological activity," Chemical \& Pharmaceutical Bulletin, vol. 44, no. 9, pp. 1647-1655, 1996.

[17] D. E. Okwu and N. Ukanwa, "Isolationand characterization of flavonoids chalcones and anthocynidines from bridelia ferruginea benth," Der Chemica Sinica, vol. 1, no. 2, pp. 21-28, 2010.

[18] G. Di Carlo, N. Mascolo, A. A. Izzo, and F. Capasso, "Flavonoids: old and new aspects of a class of natural therapeutic drugs," Life Sciences, vol. 65, no. 4, pp. 337-353, 1999.

[19] G. Achanta, A. Modzelewska, L. Feng, S. R. Khan, and P. Huang, "A boronic-chalcone derivative exhibits potent anticancer activity through inhibition of the proteasome," Molecular Pharmacology, vol. 70, no. 1, pp. 426-433, 2006.

[20] R. Ferrer, G. Lobo, N. Gamboa et al., "Synthesis of [(7chloroquinolin-4-yl)amino] chalcones: potential antimalarial and anticancer agents," Scientia Pharmaceutica, vol. 77, no. 4, pp. 725-741, 2009.

[21] A. Modzelewska, C. Pettit, G. Achanta, N. E. Davidson, P. Huang, and S. R. Khan, "Anticancer activities of novel chalcone and bis-chalcone derivatives," Bioorganic \& Medicinal Chemistry, vol. 14, no. 10, pp. 3491-3495, 2006.

[22] M. Rahman, "Chalcone: a valuable insight into the recent advances and potential pharmacological activities," Chemical Sciences Journal, vol. 29, 2011.

[23] A. H. Shridhar, J. Keshavayya, S. K. Peethambar, and H. Joy Hoskeri, "Synthesis and biological activities of Bis alkyl 1,3,4oxadiazole incorporated azo dye derivatives," Arabian Journal of Chemistry, vol. 9, pp. S1643-S1648, 2016.

[24] A. Suksamrarn, P. Poomsing, N. Aroonrerk, T. Punjanon, S. Suksamrarn, and S. Kongkun, "Antimycobacterial and antioxidant flavones from Limnophila geoffrayi," Archives of Pharmacal Research, vol. 26, no. 10, pp. 816-820, 2003.

[25] K. L. Ameta, N. S. Rathore, and B. Kumar, "Synthesis of some novel chalcones and their facile one-pot conversion to 2-aminobenzene-1, 3-dicarbonitriles using malononitrile,"
Analele Universităţii din Bucuresti - Chimie (serie nouă), vol. 20, no. 1, pp. 15-24, 2011.

[26] A. N. Chaudhary and V. Juyal, "Synthesis of chalcone and their derivatives as antimicrobial agents," International Journal of Pharmacy and Pharmaceutical Sciences, vol. 3, no. 3, pp. 125128, 2011.

[27] M. A. El-Hashash, S. A. Rizk, and S. R. Atta-Allah, "Synthesis and regioselective reaction of some unsymmetrical heterocyclic chalcone derivatives and spiro heterocyclic compounds as antibacterial agents," Molecules, vol. 20, no. 12, pp. 22069-22083, 2015.

[28] A. M. Khedr, M. Gaber, and E. H. Abd El-Zaher, "Synthesis, structural characterization, and antimicrobial activities of $\mathrm{Mn}(\mathrm{II}), \mathrm{Co}(\mathrm{II}), \mathrm{Ni}(\mathrm{II}), \mathrm{Cu}(\mathrm{II})$ and $\mathrm{Zn}(\mathrm{II})$ complexes of triazolebased azodyes," Chinese Journal of Chemistry, vol. 29, no. 6, pp. 1124-1132, 2011.

[29] P. K. Nikhil, M. P. Pratik, and R. Manoj, "Study on antibacterial activity for multidrug resistance stain by using phenyl pyrazolones substituted 3-amino $1 \mathrm{H}$-pyrazolon $(3,4$-b) quinoline derivative in vitro condition," International Journal of Pharmtech Research, vol. 3, pp. 540-548, 2011.

[30] H. Yoo, H. K. Seung, J. Lee et al., "Synthesis and antioxidant activity of 3-methoxyflavones," Bulletin of the Korean Chemical Society, vol. 26, no. 12, pp. 2057-2060, 2005.

[31] J.-S. Bae, H. S. Freeman, and A. El-Shafei, "Metallization of nongenotoxic direct dyes," Dyes and Pigments, vol. 57, no. 2, pp. 121129, 2003.

[32] H. Xu and X. Zeng, "Synthesis of diaryl-azo derivatives as potential antifungal agents," Bioorganic \& Medicinal Chemistry Letters, vol. 20, no. 14, pp. 4193-4195, 2010.

[33] T. A. Farghaly and Z. A. Abdallah, "Synthesis, azo-hydrazone tautomerism and antitumor screening of $\mathrm{N}$-(3-ethoxycarbonyl4,5,6,7-tetrahydro-benzo[b]thien-2-yl)-2-arylhydrazono-3oxobutanamide derivatives," Arkivoc, vol. 2008, no. 17, pp. 295-305, 2008.

[34] R. G. Child, R. G. Wilkinson, and A. Tomcu-Fucik, "Effect of substrate orientation of the adhesion of polymer joints," Chemical Abstracts, vol. 87, article 6031, 1977.

[35] H. G. Garg and C. Praksh, "Preparation of 4-arylazo-3,5disubstituted-(2H)-1,2,6-thiadiazine 1,1-dioxides," Journal of Medicinal Chemistry, vol. 15, no. 4, pp. 435-439, 1972.

[36] M. R. S. P. Piste, D. P. Indalkar, N. Z. Dnyandev, and S. M. Pankaj, "Synthesis and antimicrobial activity of substituted pamino azobenzene with thymol moiety- a green protocol," International Journal of Chemistry Research, vol. 3, no. 2, pp. 2529, 2012.

[37] J.-M. Noh, S.-Y. Kwak, H.-S. Seo, J.-H. Seo, B.-G. Kim, and Y.-S. Lee, "Kojic acid-amino acid conjugates as tyrosinase inhibitors," Bioorganic \& Medicinal Chemistry Letters, vol. 19, no. 19, pp. 5586-5589, 2009.

[38] Z. Ngaini, S. M. H. Fadzillah, and H. Hussain, "Synthesis and antimicrobial studies of hydroxylated chalcone derivatives with variable chain length," Natural Product Research, vol. 26, no. 10, pp. 892-902, 2012.

[39] N. B. Pappano, O. P. Centorbi, and F. H. Ferretti, "Determination of minimum concentration inhibitory chalcone derivatives," Revise Microbiology, vol. 2, no. 1, pp. 183-188, 1990.

[40] R. Mohamad, M. S. Mohameh, N. Suhaili, M. M. Salleh, and A. B. Ariff, "Kojic acid: applications and development of fermentation process for production," Biotechnology and Molecular Biology Reviews, vol. 5, no. 2, pp. 24-37, 2010. 
[41] H. Kaatz, K. Streffer, U. Wollenberger, and M. G. Peter, "Inhibition of mushroom tyrosinase by kojic acid octanoates," Zeitschrift für Naturforschung, vol. 54c, pp. 70-74, 1999.

[42] D. L. Pavia, G. M. Lampman, G. S. Kriz, and J. A. Vyvyan, Introduction to Spectroscopy, Cengage Learning, Belmont, Calif, USA, 2008.

[43] R. Bartzatt and C. Malesa, "Synthesis, structural analysis and antibacterial activity of a butyl ester derivative of ampicillin," Chemotherapy, vol. 49, no. 5, pp. 213-221, 2003.

[44] Z. Zhong, R. Xing, S. Liu, L. Wang, S. Cai, and P. Li, "Synthesis of acyl thiourea derivatives of chitosan and their antimicrobial activities in vitro," Carbohydrate Research, vol. 343, no. 3, pp. 566-570, 2008.

[45] G. M. Morris, H. Ruth, W. Lindstrom et al., "Software news and updates AutoDock4 and AutoDockTools4: automated docking with selective receptor flexibility," Journal of Computational Chemistry, vol. 30, no. 16, pp. 2785-2791, 2009.

[46] M. J. Alves, H. J. C. Froufe, A. F. T. Costa et al., "Docking studies in target proteins involved in antibacterial action mechanisms: Extending the knowledge on standard antibiotics to antimicrobial mushroom compounds," Molecules, vol. 19, no. 2, pp. 16721684, 2014.

[47] I. A. El-Kady, A. N. Zohri, and S. R. Hamed, "Kojic acid production from agro-industrial by-products using fungi," Biotechnology Research International, vol. 2014, Article ID 642385, pp. 1-10, 2014.

[48] C. I. Wei, T. S. Huang, S. Y. Fernando, and K. T. Chung, "Mutagenicity studies of kojic acid," Toxicology Letters, vol. 59, no. 1-3, pp. 213-220, 1991. 

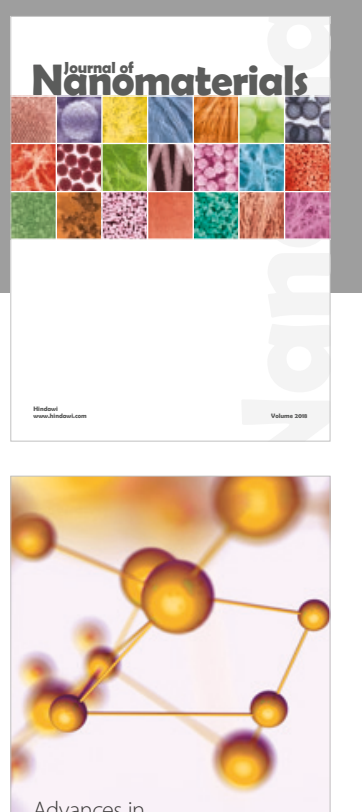

Physical Chemistry
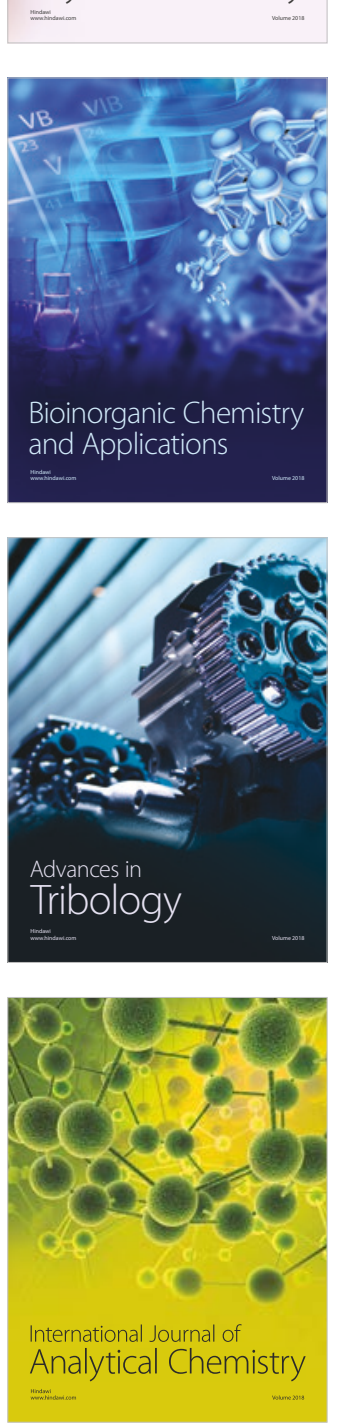

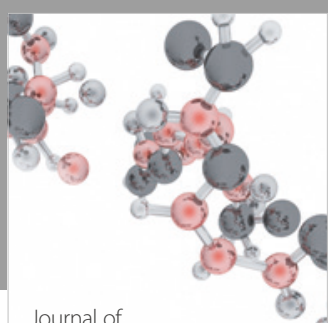

Analytical Methods

in Chemistry

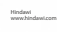

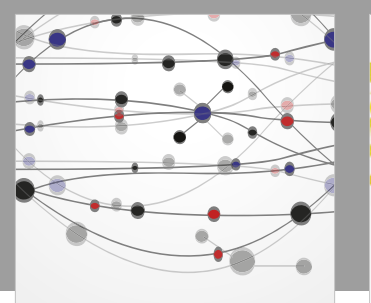

The Scientific World Journal

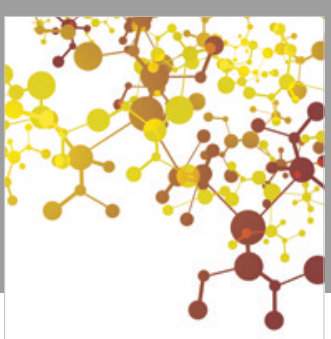

Journal of

Applied Chemistry
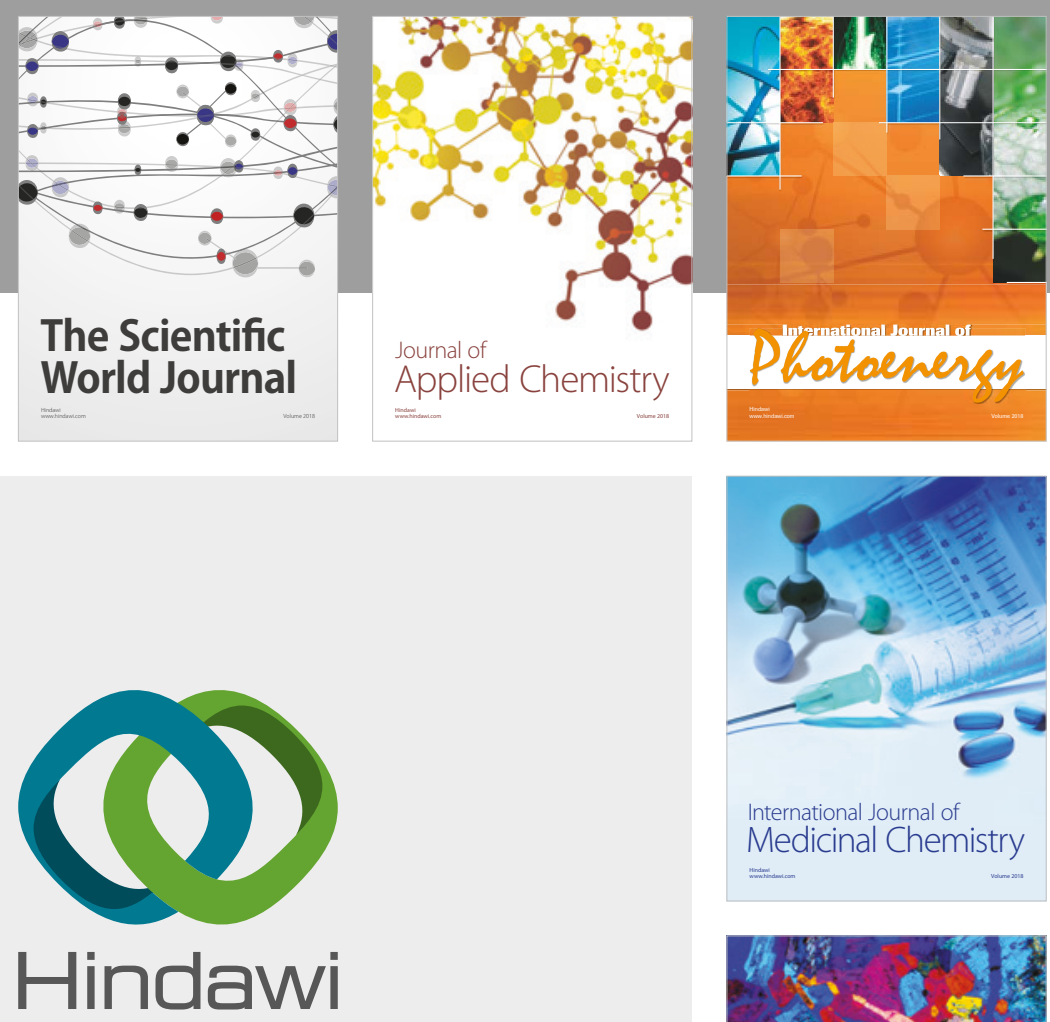

Submit your manuscripts at

www.hindawi.com
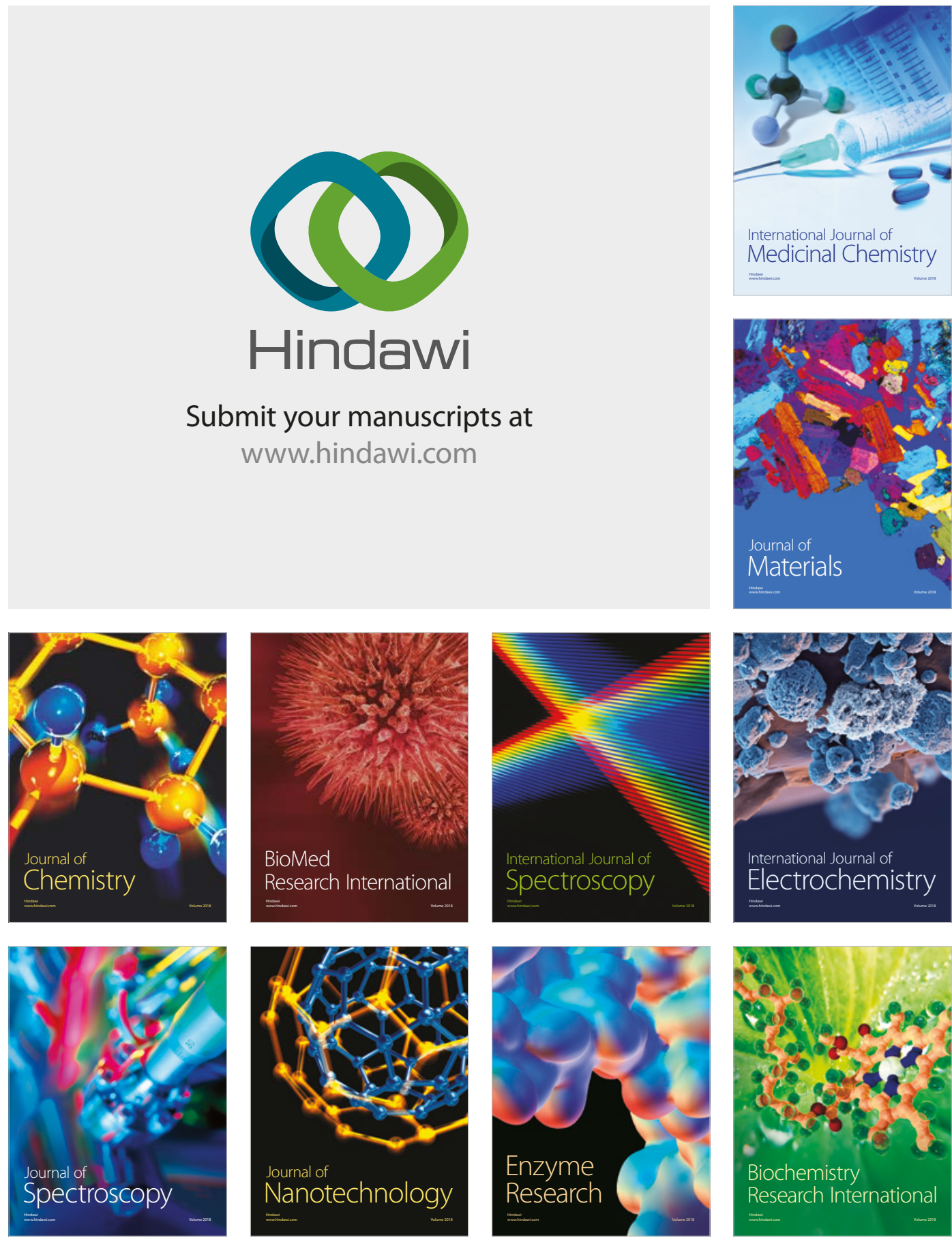
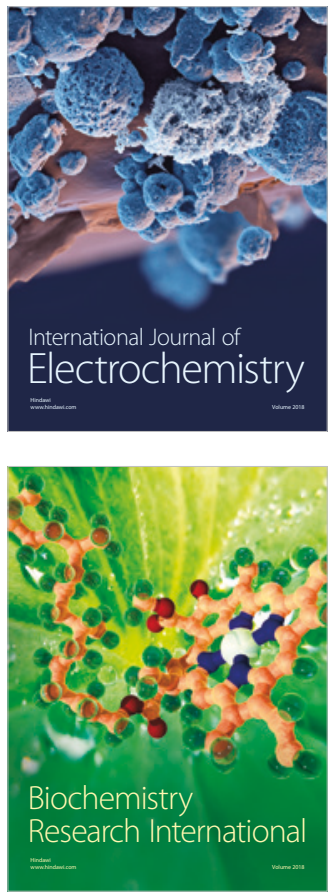